UNIVERSITY OF CHITRAL JOURNAL OF LINGUISTICS AND LITERATURE

VOL. 3 | ISSUE II | JULY - DEC | 2019

ISSN (E): 2663-1512, ISSN (P): 2617-3611

\title{
Totalitarianism and Colonial Legacy: A Postcolonial Analysis of Muhammad Hanif's A Case of Exploding Mangoes
}

\author{
Dr. Yasir Arafat \\ Assistant Professor of English, NUML Islamabad, Pakistan \\ Yasirarafat1980@gmail.com \\ Sharjeel Ahmad \\ Research Scholar, Department of English, NUML Islamabad, Pakistan \\ Muntazir Mehdi \\ Assistant Professor of English, NUML Islamabad, Pakistan \\ mmehdi@numl.edu.pk
}

\begin{abstract}
The current study has taken into consideration Muhammad Hanif's A Case of Exploding Mangoes (2008). This text is a cut-throat satire on the socio-political history of Pakistan and the interference of military in state affairs. This research highlights the elements of totalitarianism and colonial legacies practiced by General $\mathrm{Zia}$ in his dictatorial rule. This research also highlights the failure and inefficiencies of autocratic rule and spotlights the undemocratic ways of such a despotic regimes. The theoretical framework used for this study is taken from Hanna Arendt's Origin of Totalitarianism (1951) and Frantz Fanon's The Wretched of the Earth (2004). This study has contextualized the socio-political history of Pakistan discussed in the selected text and highlighted General Zia's manipulation of people by using Islamization and ideology of nationalism.
\end{abstract}

Key Words: Totalitarianism, Colonial legacy, Ideology, Nationalism, Islamization, Despotic regimes.

\section{Introduction}

The scholarship is going to highlight the elements of totalitarianism in the novel 'A Case of Exploding Mangoes' (2008) written by a Pakistani writer Muhammad Hanif. It mainly looks for the oppressive, barbaric, totalitarian, tyrannical, and colonial techniques used by the president of Pakistan (1977-1988) General Muhammad Zia-ul-Haq, a military dictator who overthrown the government of one of the most charismatic leader in the history of Pakistan, Zulfiqar Ali Bhutto by imposing martial law and begun the longest and most despotic period in the history of Pakistan. Zia took over the government and promised the people to arrange free and fair elections in 90 days, but unfortunately, his regime lasted for 11 long years. In the novel, Hanif has portrayed very skillfully with a satirical tone the real historical events in Pakistan, which finally lead to the demised of Zia in a plane crash.

Totalitarian regimes have degraded the political atmospheres of countries, destroyed the life and choices of the masses, and exploited, tortured, and marginalized. "They are decentered by the despotic tendencies of the ruling authority and the useof power and authority is highly concentrated" (Arif, 2018). During these totalitarian periods, the plights and predicaments of the masses kept pace and they become fed off from their lives. Hannah Arendt in her book Origin of Totalitarianism (1951) discussed the curses of authoritarian rules very briefly she said: "the 
purpose of modern dictatorship is not elimination rather, it demands an unquestionable obedience from the masses" (Arendt, 1951). The same thing happened in the text in which Zia is demanding the dog's loyalty from the people by force or consent and exploited the people for his political benefits using religious and national ideologies as his tools of power.

This paper will also focus on the colonial legacy maintained by Zia in his regime by practicing the policies of white masters and treating the people of his own country in an inhumane way. It was a ruling habit of colonial masters to subjugate masses and do not allow them to interfere in their actions. The same is the case with $\mathrm{Zia}$, in the novel he is serving like a comprador by trying to retain the manifesto of colonialism. Fanon says; "[The] intermediary does not lighten the oppression, nor seek to hide the domination...he is bringer of violence into the home and into the mind of the native" (p. 38).

\section{Problem Statement}

Hanif's novel A Case of Exploding Mangoes represents the political tumult in Pakistan during General Zia's administration, who used the ideologies of religion and nationalism to oppress and subjugate the people unlawfully for his satisfaction. This paper presents a far-reaching analysis of the tyranny of absolutism of totalitarian regime as portrayed by Hanif and spotlights the roles of the powers-that-be in the religio-politico environment of the Pakistani politics. Colonial traits are also addressed which is the need of the hour and to eradicate such menace from the world to give freedom to the people from their autocratic rulers. The rationale of this research is to fill the lacuna by calling the attention of the people to a comprehensive interpretation of the prevailing colonial heritage and bringing out the totalitarianism in the state during General Zia's administration.

\section{Research Objectives}

This research endeavors to achieve the following research objectives.

- To analyze the ways in which the totalitarian administration of General Zia oppressed the people of Pakistan through his tyrannical exertion by imposing different ideologies.

- To highlight the colonial legacy retained by General Zia through his undemocratic authority and autocratic norms.

\section{Research Questions}

The research paper attempts to answer the following research questions.

1. In what ways does General Zia manipulated the masses and controlled the political, social and cultural aspects during his regime?

2. How does General Zia's undemocratic authority retained colonial legacy and served the manifesto of colonialism?

\section{Significance of the Study}

This study is significant because it draws attention towardshighlighting absolutist and autocratic ways in the novel A Case of Exploding Mangoes, a historical metafiction. Further, it will bring forth into people's consciousness the efforts of standing against such evils and showing an act of defiance to any kind of dictatorial authority. The totalitarian rule automatically gives birth to a 
UNIVERSITY OF CHITRAL JOURNAL OF LINGUISTICS AND LITERATURE

colonial legacy which is only based on the exploitation and marginalization of the people. This paper attempts to highlight the fault lines in the socio-political ambiance by providing the readers with a sense of responsibility and understanding of undemocratic power over the masses.

\section{Delimitation of the Study}

The study is delimited to only one literary text i.e. Muhammad Hanif's A Case of Exploding Mangoes. The theoretical framework used for the analysis has only been taken from Hanna Arendt's Origin of Totalitarianism (1951) and Frantz Fanon's The Wretched of the Earth (2004).

\section{Literature Review}

A brief review of the literature has been given to find the implications of colonial legacy and totalitarianism. This novel can be easily applied to the socio-political history of Pakistan and articulating a universal phenomenon of undemocratic authority and colonialism. Muhammad Yar Tanvir in his article Praetorianism in A Case of Exploding Mangoes: A Critical Analysis(2014)has criticized the socio-political scenario of Pakistan in the 1980s, when General Zia take over the government by imposing martial and ruled for 11 years until his death in a plane crash. He described the role of army and the reality of Pakistani politics using the same text. Iqbal (2015) in his article has investigated the neo-colonial aspects of the novel. He criticized Zia's regime for using religious ideologies and Islamization for exploiting and manipulating the people. Sunder Huma et al. authored an article A Case of Exploding of Mangoes: Postmodernist Analysis (2018) analyzed the novel from a postmodern perspective and claimed it as a 'Black Comedy'; a prominent feature of the postmodern text. She has gravely satirized the influence of the military in politics. Mubashar Altaf deconstructs in his research $A$ Barthesian critique of Mohammad Hanif's novel A Case of Exploding Mangoes (2019) the myths and heroic beliefs of the people about General Zia. He further investigated that it was a social trick used by Zia and that's why he was famous among the masses with the name of 'Man of Truth' and 'Man of Faith. He reported in a very crystal clear manner that these historical beliefs of people about General Zia are only myths and myths do not occur naturally. Hafsa Niabat et al. in their research 'The geometry of God and A Case of Exploding Mangoes' (2020) used the comparative method for analyzing both postmodern novels. This study investigates the social and political situations of Pakistan during General Zia's administration. Both the novels have deeply criticized the interference of military in politics of Pakistan.

\section{Methodology and Theoretical Framework}

This research is reflexive and qualitative in approach which is based on textual analysis of Hanif's novel A Case of Exploding Mangoes (2008). As qualitative research is based on personal interpretations of the researcher the same has been used by the scholar as well and mentioned the opinions, ideas and researches of other scholars for adding value to the conclusion of study.

For analyzing the text of A Case of Exploding Mangoes two major perspectives have been used as a theoretical framework. First is the perspective to analyze the totalitarian authority of General Zia and for that Hannah Arendt's concept of totalitarianism is very suitable which she discussed in her book Origin of Totalitarianism (1951). Second is the idea of the colonial legacy for which the researcher has used postcolonial theorist Frantz Fanon's (2004) concept of inferences about colonial legacy and its practitioners from his book The Wretched of the Earth. 


\begin{abstract}
Analysis and Discussion
A Case of Exploding Mangoes is a satirical novel, which has unleashed the mystery of the sociopolitical history of Pakistan during the dictatorial regime of General Zia and has become a matter of special attention for Mohammad Hanif to enlightened the people by using "Black Comedy" influenced by his own military experiences and the military corruptness in the shape of religious improvisation. Hanif has used Ali Shigri, a junior officer at Pakistan Air Force as his mouthpiece who is seeking to assassinate General Zia in revenge for the death of his father. Hanif has mainly focused on Zia's political and social life and his manipulation of the masses by using different ideologies.
\end{abstract}

\title{
Totalitarianism in Zia's Administration
}

The curse of the centrality of authority was a prevailing concept during the $20^{\text {th }}$-century world, which has devastated the lives of millions of people across the globe, for instance, Hitler, Stalin and Mussolini did the same and imposed on the masses what Shashi Tharoor in his book An Era of Darkness (2016) called "Draconian Restrictions" and caused havoc in the form of two world wars by using their horrendous policies. In a totalitarian regime the authority use power, threat, force, coercion, and other horrible oppressions to suppress the masses and make them marginalized in own state. In the moral sphere, all these techniques and tactics are unjustified and wholly based on personal political benefits. Similarly, in the novel, A Case of Exploding Mangoesthe protagonist Ali Shigri says that "You want freedom and they give you chicken korma" (p.127). Ali knows that it was General Zia who killed his father so he makes a plane to take his revenge. Up till now, he has not started anything about that plane but Zia was afraid of him and order the ISI to arrest and imprison him. Such days of despotism make daily life affairs a forbidden fruit for them Arif et al. (2018). It is very difficult for the dictatorial power to suppress every person with tyranny because it will aggravate the social and political situation of the country. In the novel, another man who was the secretary-general of the All Pakistan Sweeper Movement has been imprisoned for 9 years without any charge. Everyone during Zia's regime was supposed to blindly follow the orders without any resistance. "Every member of the Pakistan Sweepers' Union believes in political struggle," he says grandly" (p.126). Hanna Arendt in her book Origin of Totalitarianism (1951) stated that

"A fundamental difference between modern dictatorship and all the other tyrannies of the past is that terror is no longer used as means to exterminate and frighten opponents, but an instrument to rule masses of people who are perfectly obedient" (Arendt, 1951).

This idea of suppressing the masses will not run for a longer time because the more you marginalized them the more they will become radicalized and finally outbursts into a bloody revolution. It is a very pitiable situation that the job of the military is to protect the state from the opponent attacks but here things are topsy-turvy as Arendt has explained it beautifully that such totalitarian and despotic authority use power and force against its people. "State use coercion in every aspect of life" (Arendt, 1951).

Zia used Islamization and the ideology of nationalism to manipulate the minds of the people for his political interests. In the novel, we can see many instances that Zia posed to be a religious man to get the support of religious groups. He was famous with the names of "Man of Faith", "Man of Truth" and "Friend of Widows". Here Hanif draws a satirical picture of Zia by claiming 
him "nothing but a tit ogler" (p.145). In the novel, the first lady says that he is not a friend of widows rather he is morally a degraded person who needs to be admired by women. Zia used religion as a tool so that people would start loving him as a good Muslim and support him in his political manifesto while on the other hand, he used power to suppress people who stood against his monolithic laws. As in the novel Ceausescu advised Zia "the key (to Power) is they should either love you or fear you, your decline starts the day they become indifferent to you. (p.275). Inthe novel, we can easily notice how Zia is using the army and ISI for abducting and eliminating people who speak against him. Bendersky has given an exquisite definition of Totalitarianism in his book A Concise History of Nazism (2014) and which we can easily relate with Zia's rule "A society in which party and its ideology would permeate in every aspect of public and private life".

\section{Zia's Colonial Legacy}

Frantz Fanon has explored the hypocritical face of those native people who are serving and promoting the manifesto and legacy of colonizers without knowing the morbid consequences of such actions. In A Case of Exploding Mangoes Hanif has narrated such events in which General $\mathrm{Zia}$ is treating the subjects of the state like slaves. Sartre said in his preface to The Wretched of the Earth (2014) that "Fanon reveals to his comrades, above all some of them who are rather too westernized" (p.218). In the undemocratic regime of Zia he was the only one that everyone should obey him and answerable for his/her deeds to him but he was answerable to no one like in the colonial time the Viceroy was not answerable to anyone of the colonized and treated them like slaves. The colonial legacy of master and slave is very prominent during the dictatorship of General Zia. Fanon Says "The intermediary does not lighten the oppression, nor seek to hide domination... he is the bringer of violence into the home and into the mind of native" (p.38)

Similarly in the novel, we see many instances that are based on corruption, dominance, and exploitation of people. From a postcolonial perspective, General Zia is a crystal clear representative icon of the colonizing world and white masters. He corrupted the sacred notions of religion and portrayed a wrong picture of Islamic conservatism and fundamentalism to the whole world. He took control of the media to manipulate the minds of the people which was a prominent tactic of colonizers. Shashi Tharoor in his book An Era of Darkness (2016) says that "the newspapers and other media all reflected the interests of small European community" (Tharoor, 2016). In the novel, we can notice that Zia left no stone unturned to use the media for his political gains. As Ali says "the only newspaper we get in academy is the Pakistan Times, which on any given day has a dozen pictures of General Zia”. (p.124). It is very much obvious that Zia was not only a mere retainer of Colonial legacy but his character in the novel portrays hypocrisy, egoistic attitude, revenge, conservatism, corruption, political incompetence, and moral decadence.

\section{Conclusion}

To conclude, this research paper has highlighted different elements of the totalitarian regime and colonial legacy practiced by General Zia in the selected text. The research has brought these dangerous autocratic policies to the limelight and focused on the resulting consequences. The elements of totalitarianism, which this research work has found are the use of force, coercion, threat, killing, abducting, and imprisoning those people who stood against these autocratic 
policies. Colonial legacy in the form of master-slave relationship between authority and masses and censorship of media is very prominent in the novel.

\section{References}

Altaf, Mubashar. "International Journal of Research in English." 2019.

Arendt, Hannah. "The Origins of Totalitarianism [1951]." New York .1973.

Arif, Muhammad, Humaira Ahmed, and Bakht Rahman. "Dismantling Panopticonic Regime: Study of Orwell's 1984." Liberal Arts and Social Sciences International Journal (LASSIJ), 2018.

Arif, Muhammad, Humaira Ahmed, and Bakht Rahman. "Highlighting the Undemocratic Hegemony of Totalitarian Regime: An Analysis of Bisma's The Queue." Liberal Arts and Social Sciences International Journal (LASSIJ), 2018.

Bendersky, Joseph W. A concise history of Nazi Germany. Rowman\& Littlefield Publishers, 2014.

Fanon, Frantz. The wretched of the earth. Grove/Atlantic, Inc., 2004.

Huma, S., Bhatti, A.I, Ali, H. A Case of Exploding of Mangoes: Postmodernist Analysis (2018)

Hanif, Mohammed. A Case of Exploding Mangoes. New Delhi: Random House India .2008.print

Iqbal, M. A., M. S. Arif, and A. Jamil. "An analysis of the role of comprador class: A neocolonial study of a case of exploding mangoes by Hanif." British Journal of English Linguistics, 2015.

Manzoor, Fahmida. "A Comparative Analysis of 'The Geometry of God and a Case of Exploding Mangoes' in the Framework of Postmodernism, 2016.

Siddiqa, Ayesha. Military Inc.: inside Pakistan's military economy. Penguin Random House India, 2017.

Tanvir, Muhammad Yar, Shahbaz Arif, and MAZHAR HAYAT. "Praetorianism in A Case of Exploding Mangoes: A Critical Analysis." (2018).

Tharoor, Shashi. An era of darkness. Aleph, 2016. 